\title{
COLOBANTHUS CURTISIAE (CARYOPHYLLACEAE), A NEW SPECIES FROM EASTERN TASMANIA, AUSTRALIA
}

\author{
by J.G. West
}

(with two text-figures and one plate)

A new species of Colobanthus, C. curtisiae, from the Ben Lomond and Midlands regions of Tasmania, is described and illustrated, and its affinities within the genus are discussed. C. curtisiae is an endangered species known only from two populations.

Key Words: Tasmania, Caryophyllaceae.

In BANKS, M.R. et al. (Eds), 1991 (31:iii): ASPECTS OF TASMANIAN BOTANY - A TRIBUTE TO WINIFRED CURTIS. Roy. Soc. Tasm. Hobart: 75-77. https://doi.org/10.26749/rstpp.124.2.75

\section{INTRODUCTION}

Colobanthus is often cited as an example of a genus showing southem circum-temperate distribution (e.g. Thome 1972, Good 1974). About 20 species are recognised at present in the genus, with the major diversity occurring in New Zealand. It exhibits a Gondwanan distribution, occurring in South America (Colobanthus quitensis extends north along the Andes and in Mexico (Moore 1970)), the Antarctic Peninsula, and the Australasian area including New Zealand, Australia and the sub-antarctic islands such as Macquarie Island. Colobanthus crassifolius is the only dicotyledonous species known fromAntarctica (Holtom \& Greene 1967).

Until now there have been four species recognised in Australia, all occurring in southeastern Australia. Two species, Colobanthus nivicola and $C$. pulvinatus, are endemic to the Kosciusko region, although recently C. pulvinatus has been reported from Tasmania (Buchanan et al. 1989). C. affinis and C. apetalus occur on the southern tablelands of New South Wales, south through Victoria and southeastern South Australia to Tasmania.

The species described in this contribution has come to my attention through the efforts of enthusiastic Tasmanian botanists and collectors. In contrast to C. affinis and $C$. apetalus, which are widespread throughout the state, the new species Colobanthus curtisiae, is recorded from only three populations. All of these have been located in the past few years, and one population has recently been destroyed.

\section{TAXONOMY}

\section{Colobanthus curtisiae J.G. West, sp.nov.}

A Colobanthus apetalo sepalis longioribus angustioribus capsulam multum excedentibus, apicibus foliorum longioribus (1-2 $\mathrm{mm}$ ) et testa colliculosiore differt.

\section{Typus}

Tasmania: Midlands (regions as Orchard 1988) $3.8 \mathrm{~km}$ northwest of Tunbridge on Tunbridge Tier road to Interlaken, J.G.West 5159, 17.i.1990. Holotypus: CANB 393093.

\section{Description}

Glabrous tufted perennial herbs to $40 \mathrm{~mm}$ high, forming small clumps from laterally branching short stems. Leaves sessile, soft and spreading, densely crowded, subulate, the lamina $25-30 \mathrm{~mm}$ long, 1-2 mm wide, margin entire, with membranous sheathing base, thickened and \pm triquetrous towards the apex and abruptly contracted into a fine hair-like translucent (cream-coloured when dry) tip 1-2 mm long. Inflorescence of solitary, terminal, pedunculate flowers. Peduncles $2.5-3 \mathrm{~mm}$ long, extending to $25 \mathrm{~mm}$ in fruit, fruiting peduncles slightly shorter than the leaves. Flowers solitary, terminal, 5-merous; sepals 5, persistent, green, narrow-triangular, 4--4.5 mm long, 1-1.5 mm wide, thickened towards the apex and contracting to a fine hair-like tip of $0.5-0.7 \mathrm{~mm}$ long, longer than the capsule; petals 0 ; stamens 5 , anthers c. $0.5 \mathrm{~mm}$ long, filaments c. $0.6 \mathrm{~mm}$ long, flattened; ovary one-celled, ovoid, c. $1.2 \mathrm{~mm}$ long, styles 5 , c. $0.3 \mathrm{~mm}$ long and apparently free for most of their length, ovules many. 
Capsule ovoid, opening by valves shorter than and alternating with the sepals, the valves $3-4 \mathrm{~mm}$ long, 1.5-2 mm wide, elliptic, obtuse at apex and incurved after dehiscence. Seeds red-brown, obovoid, colliculate, $0.5 \mathrm{~mm}$ long, $0.3 \mathrm{~mm}$ wide (fig 1, pl. 1).

This species is named in honour of Dr Winifred Curtis, in recognition of her very significant contribution to the systematics of the Tasmanian flora and to education.

\section{Distribution and Ecology}

Colobanthus curtisiae is now known from only two populations - one in Ben Lomond National Park (at $1300 \mathrm{~m}$ altitude) and the other in the Midlands region near Tunbridge (fig. 2). At the latter site it occurs in Eucalyptus rodwayi-Acacia dealbata remnant woodland at an altitude of $240 \mathrm{~m}$ in light sandy soil by the roadside. Associated taxa include herbaceous species such as Poa rodwayi, P. hookeri, Helichrysum. apiculatum, Plantago varia and Scleranthus biflorus. The species has also been recorded from the Campbell Town cemetery, but that site of remnant Eucalyptus pauciflora-Acacia dealbata woodland was recently subjected to domestic stock grazing and fire, and much of the natural vegetation has been destroyed.

\section{Breeding System}

Colobanthus curtisiae is self-compatible and appears to be largely self-pollinated. The anthers dehisce in close proximity to the stigmas at anthesis, and indeed some flowers appear to be cleistogamous. Many fertile seeds, with a high germination rate, are released from each capsule.

\section{Affinities}

Colobanthus curtisiae is allied to C. apetalus to which it also shows some morphological resemblance. The new species can be distinguished through its sepals, which are narrower and longer than in $C$. apetalus, the hair-like leaf tip is 1-2 $\mathrm{mm}$ long compared with

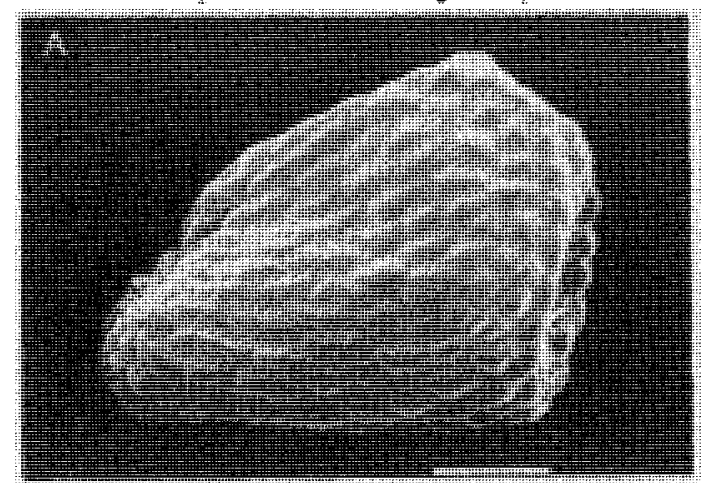

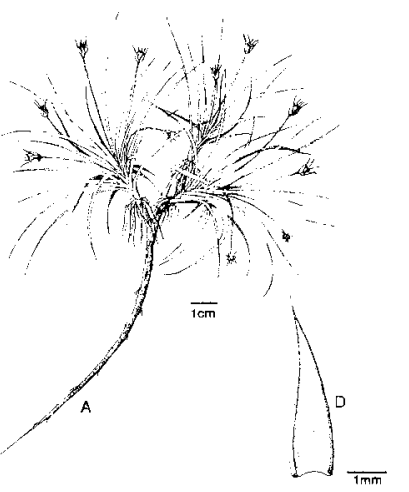

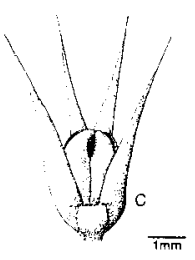

FIG. I Colobanthus curtisiae: (A) part of a fruiting plant, $(B)$ capsule at dehiscence (one sepal removed), (C) capsule with incurved valves after dehiscence (one sepal removed), (D) sepal-adaxial view.

c. $0.5 \mathrm{~mm}$ in C. apetalus and the testa pattern is more prominently colliculate.

There is some superficial similarity between C. curtisiae and the alpine New Zealand species C. strictus, but the latter differs from the endemic Tasmanian species in several characters including its dense cushion habit and larger flowers.

\section{Additional Specimens Examined}

Tasmania: Ben Lomond - J.B. Davies (CANB, HO); Midlands - R. Fensham (CANB - spirit). [Further details of specimens listed in this paper, e.g. collecting site and date, are available from the Herbaria noted or from the Royal Society of Tasmania Library (Archives), GPO Box 1166M, Hobart, Tasmania, Australia 7001. Ed.]

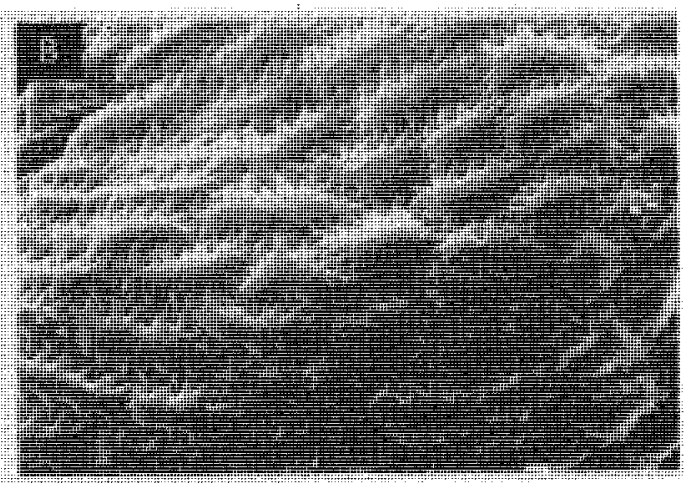




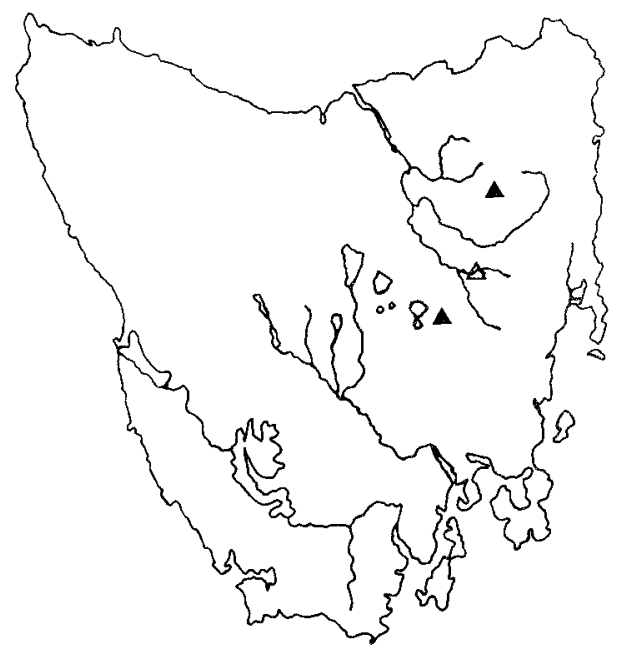

FIG. 2-Distribution of Colobanthus curtisiae. Extant populations $(\mathbf{A})$, population presumed extinct $(\Delta)$.

\section{Discussion}

The limited amount of Colobanthus curtisiae material available means that the sample size on which to make thorough comparisons with other species is rather small. It is clearly closely related to $C$. apetalus, but its position in the genus as a whole must await the results of a more in-depth study of all the Australian taxa and the relevant New Zealand and South American species.

\section{Population Sites}

Colobanthus curtisiae is an endangered species and is presently known from only two populations. Fortunately, one of these is reserved in a national park, although at the time of collection only two plants could be found. The other population, consisting of about 20 plants, is in a vulnerable position on a roadside verge and in the adjacent paddock in the Tunbridge area in the Midlands region. This site will need careful management if the remnant woodland is to survive and to provide some chance for a viable reproducing population of C. curtisiae.

The Campbell Town cemetery was the only known site for $C$. curtisiae when it was first discovered. This remnant patch of valuable native vegetation was selected by the local authorities for a "tidy up" operation and the site was grazed by domestic stock. In the process the Colobanthus population was possibly destroyed (Kirkpatrick et al. 1988 - as C. strictus). A thorough search of the cemetery early in 1990 failed to locate any plants of this species.

\section{Conservation Status}

In the national list of rare or threatened plant species Briggs \& Leigh (1988) recorded this taxon, as C. strictus, with a categorisation of $2 \mathrm{E}$ (Endangered, with geographic range $<100 \mathrm{~km}$ ). Colobanthus curtisiae is now classified as $2 \mathrm{ECi}$ - the " $\mathrm{i}$ " indicating that the species is inadequately reserved and recognising that, to this time, only two plants have been found in any conservation area (Briggs, pers. comm.).

\section{ACKNOWLEDGEMENTS}

I thank various members of the Tasmanian Herbarium (HO) for drawing my attention to this new species and for their cooperation in supplying material and information. Other members of the Tasmanian botanical community, including Louise Gilfedder, provided encouragement and data. At different times, Tony Orchard and Louise Gilfedder kindly joined me in the field, crawling around searching for these belly plants. Technical assistance was provided by Cathy Miller and Frank Zich. My thanks are due to Cathy Miller for the SEM and to Elaine Cooper for the line drawing. Ian Brooker checked the Latin diagnosis.

\section{REFERENCES}

BRIGGS, J.D. \& LEIGH, J.H., 1988: RARE OR THREATENED AUSTRALIAN PLANTS: 1988 REVISED EDITION. Aust. Nat.Pks \& Wildl. Serv. Spec. Publ. 14: 278 pp.

Buchanan, A.M., McGeary-Brown, A. \& Orchard, A.E., 1989: A CENSUS OF THE VASCULAR PLANTS OF TASMANIA. Tasm. Herb. Occas. Publ. 2.

GoOD, R., 1974: THE GEOGRAPHY OF THE FLOWERING PLANTS. 4th edn, Longman, London.

Holtom, A. \& Greene, S.W., 1967: The growth and reproduction of Antarctic flowering plants. Phil. Trans. R. Soc. Lond. B. Biol. 252: 323-337.

Kirkpatrick, J., Gilfedder, L. \& Fensham, R., 1988: CiTY PARKS AND CEMETERIES - TASMANIA'S REMNANT GRASSLANDS AND GRASSY WOODLANDS. Tasmanian Conservation Trust, Hobart.

Moore, D.M., 1970: Studies in Colobanthus quitensis (Kunth) Bartl. and Deschampsia antarctica Desv.: II. Taxonomy, distribution and relationships. Brit. Antarct. Surv. Bull. 23: 63-80.

ORCHARD, A.E., 1988: A natural regions map for Tasmania. Pap. Proc. R. Soc. Tasm. 122(2): 47-51.

Thorne, R.F., 1972: Major disjunctions in the geographic ranges of seed plants. Quart. Rev. Biol. 47:365-411.

$$
\text { (accepted } 10 \text { August 1990) }
$$

J.G. West

Australian National Herbarium, CSIRO, PO Box 1600 , Canberra, ACT, Australia 2601 